Iwona Orłowska, Ph.D. ${ }^{a)}$; prof. Marek Dziubiński, D.Sc. ${ }^{\text {a) }}$

a) Łódź Univeristy of Technology, Faculty of Process and Environmental Engineering / Politechnika Łódzka, Wydział Inżynierii Procesowej i Ochrony Środowiska

Corresponding author / Autor korespondencyjny: marek.dziubinski@p.lodz.pl

\title{
The application of Greenberg's Model Modification for Estimating the Evacuation Time of People from Public Utility Buildings
}

\section{Zastosowanie modyfikacji modelu Greenberga do szacowania czasu ewakuacji ludzi z budynków użyteczności publicznej}

\begin{abstract}
Objective: The article presents a proposition of a model for estimating people's evacuation time from public utility buildings of category ZL III (not containing rooms designed for the simultaneous presence of more than 50 people who are not their regular users, not primarily intended for use by people with limited mobility). The model is based on the analogy between the theory of road traffic and the process of people's movement during evacuation. Design and methods: In order to develop the model, a series of trial evacuations of people from public utility category ZL III buildings of varied geometry and number of users was conducted. A comparative analysis was performed concerning the evacuation times calculated with the use of models available in literature - a critical model of evacuation time, models designed by Togawa, Melenik and Booth, Galbreath, Pauls, methodology of the British Standard, and those derived from computer simulations performed with the use of the Pathfinder software. Based on the analysis of the conducted research and model considerations, an equation for the estimation of evacuation time was proposed based on a modified Greenberg's equation derived from the road traffic theory. In the model modification, the concept of replacement length of evacuation route elements was applied, significantly slowing down people's movement velocity, and a method for calculating them was proposed.

Results: The evacuation times obtained in experimental research were compared to the model time values calculated from the models published in literature. A considerable dispersion of the achieved results was shown, ranging from $-65.0 \%$ to $+425.8 \%$ with respect to the evacuation times obtained experimentally. The performance of computer simulations brought evacuation times with a bias ranging from $-54.4 \%$ to $+26.0 \%$ with respect to the experiments conducted. Evacuation times calculated with the use of the proposed equation were in line with the experimental results with an error ranging from $-12.3 \%$ to $+13.8 \%$. However, in comparison to the times obtained from additional computer simulations, representing the description of evacuation from buildings with highly varied geometry and various numbers of evacuees, the deviation of the calculated evacuation time from the proposed model was from $-16.7 \%$ to $+23.1 \%$. In the vast majority of cases, the deviation of the result oscillated around $\pm 15 \%$ for a wide range of buildings' geometry and the number of evacuees.

Conclusions: The proposed model makes it possible to determine with sufficient accuracy the evacuation time of people from public utility buildings of category ZL III and can serve as a reliable source of comparative information.

Keywords: experiment, evacuation, transition time, evacuation time

Type of article: original scientific article
\end{abstract}

Received: 18.03.2019; Reviewed: 12.04.2019; Accepted: 30.06.2019;

Authors' ORCID IDs: I. Orłowska - 0000-0002-7134-0542; M. Dziubiński - 0000-0002-0208-3570;

Percentage contribution: I. Orłowska - 75\%; M. Dziubiński - 25\%;

Please cite as: SFT Vol. 53 Issue 1, 2019, pp. 88-105, https://dx.doi.org/10.12845/sft.53.1.209.5;

This is an open access article under the CC BY-SA 4.0 license (https://creativecommons.org/licenses/by-sa/4.0/). 


\section{ABSTRAKT}

Cel: Artykuł przedstawia propozycję modelu szacowania czasu ewakuacji ludzi z budynków użyteczności publicznej ZL III (niezawierających pomieszczeń zaprojektowanych do jednoczesnego przebywania ponad 50 osób niebędących ich stałymi użytkownikami oraz nieprzeznaczonych w szczególności do użytku przez ludzi o ograniczonej zdolności poruszania się). Zaproponowany model bazuje na analogii między teorią ruchu drogowego a procesem przemieszczania się ludzi w trakcie ewakuacji.

Projekt i metody: Przeprowadzono szereg próbnych ewakuacji ludzi z budynków użyteczności publicznej ZL III o różnej geometrii i liczbie użytkowników. Dokonano analizy porównawczej czasów ewakuacji obliczonych za pomocą dostępnych w literaturze modeli - modelu krytycznego czasu ewakuacji, Togawy, Melenika i Bootha, Galbreatha, Paulsa, metodyki British Standard oraz otrzymanych z symulacji komputerowych wykonanych za pomocą programu Pathfinder. Na podstawie analizy wykonanych badań oraz przeprowadzonych rozważań modelowych zaproponowano równanie szacowania czasu ewakuacji oparte na modyfikacji równania Greenberga wynikającego z teorii ruchu drogowego. W modyfikacji modelu zastosowano koncepcję długości zastępczej elementów dróg ewakuacyjnych znacząco spowalniających prędkość poruszania się ludzi i zaproponowano metodę ich obliczania. Wyniki: Porównano uzyskane w badaniach eksperymentalnych czasy ewakuacji z modelowymi wartościami czasów obliczonymi z opublikowanych w literaturze modeli. Wykazano, duży rozrzut otrzymanych wyników wynoszący od -65,0\% aż do +425,8\% w stosunku do uzyskanych eksperymentalnie czasów ewakuacji. Wykonując symulację komputerową, uzyskano czasy ewakuacji obarczone błędem od $-54,4 \%$ do $+26,0 \%$ w stosunku do przeprowadzonych eksperymentów. Obliczone czasy ewakuacji za pomocą zaproponowanego równania zgadzały się z wynikami eksperymentalnymi z błędem od -12,3\% do $+13,8 \%$. Natomiast w porównaniu z czasami uzyskanymi z dodatkowych symulacji komputerowych, reprezentujących opis ewakuacji z budynków o bardzo różnej geometrii i różnej liczbie ewakuujących się ludzi, odchylenie wyniku obliczanego czasu ewakuacji z zaproponowanego modelu wyniosło od $-16,7 \%$ do $+23,1 \%$. W zdecydowanej większości przypadków odchylenie wyniku oscylowało w granicach około $\pm 15 \%$ dla szerokiej gamy geometrii budynków oraz różnej liczby ewakuujących się osób.

Conclusions: Zaproponowany model pozwala na wyznaczenie z zadowalającą dokładnością czasu ewakuacji ludzi z budynków użyteczności publicznej ZL III i może stanowić wiarygodne źródło informacji porównawczych.

Słowa kluczowe: eksperyment, ewakuacja, czas przejścia, czas ewakuacji

Typ artykułu: oryginalny artykuł naukowy

Przyjęty: 18.03.2019; Zrecenzowany: 12.04.2019; Zatwierdzony: 30.06.2019;

Identyfikatory ORCID autorów: I. Orłowska - 0000-0002-7134-0542; M. Dziubiński - 0000-0002-0208-3570.

Procentowy wkład merytoryczny: I. Orłowska - 75\%; M. Dziubiński - 25\%;

Proszę cytować: SFT Vol. 53 Issue 1, 2019, pp. 88-105, https://dx.doi.org/10.12845/sft.53.1.209.5;

Artykuł udostępniany na licencji CC BY-SA 4.0 (https://creativecommons.org/licenses/by-sa/4.0/).

\section{Introduction}

The basic fire safety requirement for buildings is to provide people staying in them with evacuation options [4]. Safe evacuation from a building in case of fire is the priority fire protection measure [5]. It is described on the basis of ASET (Available Safe Evacuation Time) and RSET (Required Safe Escape Time) [6-8]. Various tools can be applied in order to determine ASET and RSET, including empirical data (obtained, e.g., on the basis of real-scale tests, laboratory tests or practice evacuations), normative data specified in fire regulations and technical standards, computational models of evacuation time, computational models of temperature increase in a room as well as an increase in fogging, and simulation software based on the aforementioned models. Literature on the subject contains a considerable number of computational models of the transition time of people during evacuation. They differ in the complexity of computations and, primarily, in the accuracy of the obtained evacuation times [1].

In order to develop a proprietary model, a number of practice evacuations were arranged from public utility buildings of category ZL III with varying geometries and number of users. A comparative analysis was performed of evacuation times

\section{Wstęp}

Podstawowym wymaganiem odnoszącym się do bezpieczeństwa pożarowego budynków jest zapewnienie przebywającym w nich ludziom możliwości ewakuacji [4]. Bezpieczna ewakuacja z obiektu w przypadku pożaru jest priorytetowym działaniem w zakresie ochrony przeciwpożarowej [5]. Opisuje się ją na podstawie dostępnego czasu bezpiecznej ewakuacji (ASET) oraz wymaganego czasu bezpiecznej ewakuacji (RSET) [6-8]. Do ich wyznaczenia można stosować różne narzędzia, takie jak: dane empiryczne (uzyskane np. na podstawie przeprowadzonych testów w skali rzeczywistej, badań laboratoryjnych lub ćwiczeń praktycznych - próbnej ewakuacji), dane normatywne określone w przepisach przeciwpożarowych i standardach technicznych, modele obliczeniowe czasu ewakuacji, przyrostu temperatury w pomieszczeniu i wzrostu zadymienia oraz komputerowe programy symulacyjne oparte na wspomnianych powyżej modelach. W literaturze przedmiotu znaleźć można znaczną liczbę modeli obliczeniowych czasu przejścia ewakuujących się ludzi. Różnią się one między sobą złożonością prowadzonych obliczeń oraz - przede wszystkim - dokładnością uzyskanych czasów ewakuacji [1].

W celu opracowania własnego modelu przeprowadzono szereg próbnych ewakuacji z budynków użyteczności publicznej 
calculated with the models available in literature: the critical evacuation time, the Togawa, Melenik and Booth, Galbreath, Pauls models, the British Standard methodology and models obtained from computer simulations performed with the Pathfinder software [1]. The evacuation times obtained in experiments were compared with the model time values calculated on the basis of models available in literature. A high dispersion of the results was identified from $-65.0 \%$ to as many as $+425.8 \%$ in comparison to evacuation times obtained in experiments. In the computer simulation with a bias ranging from $-54.4 \%$ to $+26.0 \%$ as compared to the experiments [2].

Due to the above, a proprietary equation was proposed for estimating the transition time of evacuated people that would describe the analysed process with a higher accuracy.

\section{The traffic theory and the movement of evacuated people}

The analysis of literature on traffic theory makes it possible to draw an analogy between the description of vehicles moving in traffic and the process of people's evacuation from buildings [3]. The originator of the hydrodynamic theory, also referred to as the continuity theory, was Greenberg [3]. He suggested equation (1), which is correct if the differentiability condition of intensity $q$ and traffic density $k$ is satisfied.

$$
q=k \cdot \bar{v}_{o p t} \cdot \ln \left(\frac{k_{\max }}{k}\right)
$$

where:

$\bar{v}_{\text {opt }}$ - optimum momentary velocity of traffic;

$\mathrm{k}_{\max }$ - traffic density in a traffic jam.

The analysis of the traffic theory bears considerable resemblance to the process of evacuating people from buildings and can be applied for this purpose for the following reasons:

1) in order for movement to start, an impulse must occur - in the case of vehicles this is usually a change of traffic lights, and in the case of people - a sound signal or voice message alarming of the fire;

2) velocity of vehicles changes depending on their density, similarly to people in motion: when their density increases, their velocity drops, and conversely, when the density of people on escape routes decreases, people move at a higher velocity;

3) similarly to vehicles in traffic, people move, collide with each other, pass obstacles, accelerate on straight road passages, when their density is low, and slow down, especially when changing direction;

4) the trajectory of vehicles and evacuees is not straightforward. In both cases it depends on people's decisions and behaviour, which are difficult to predict;
ZL III o zróżnicowanej geometrii i liczbie użytkowników. Dokonano analizy porównawczej czasów ewakuacji obliczonych za pomocą dostępnych w literaturze modeli: krytycznego czasu ewakuacji, Togawy, Melenika i Bootha, Galbreatha, Paulsa, metodyki British Standard oraz modeli otrzymanych z symulacji komputerowych wykonanych za pomocą programu Pathfinder [1]. Uzyskane w eksperymentach czasy ewakuacji porównano z modelowymi wartościami czasów obliczonymi na podstawie opublikowanych w literaturze modeli. Wykazano duży rozrzut otrzymanych wyników wynoszący od $-65,0 \%$ aż do $+425,8 \%$ w stosunku do uzyskanych eksperymentalnie czasów ewakuacji. W symulacji komputerowej uzyskano czasy ewakuacji obarczone błędem od $-54,4 \%$ do $+26,0 \%$ w stosunku do przeprowadzonych eksperymentów [2].

W związku z powyższym zaproponowano własne równanie do szacowania czasu przemieszczania się ewakuujących się ludzi, które z większą dokładnością opisałoby analizowany proces.

\section{Teoria ruchu drogowego a ruch ewakuujących się ludzi}

Analiza literatury na temat teorii ruchu drogowego pozwala dostrzec analogię między opisem poruszania się pojazdów na drogach a procesem ewakuacji ludzi z budynków [3]. Prekursorem zastosowania analogii hydrodynamicznej, znanej również pod pojęciem teorii ciągłości, był Greenberg [3]. Zaproponował on równanie (1), słuszne, jeśli spełniony jest warunek różniczkowalności natężenia $q$ (intensywności) i gęstości ruchu $k$ pojazdów.

$$
q=k \cdot \bar{v}_{o p t} \cdot \ln \left(\frac{k_{\max }}{k}\right)
$$

gdzie:

$\bar{V}_{o p t}$ - optymalna prędkość chwilowa ruchu pojazdów;

$\mathrm{k}_{\max }$ - gęstość ruchu w sytuacji korka drogowego.

Analiza teorii ruchu drogowego pozwala dostrzec jej znaczące podobieństwo do opisu procesu ewakuacji ludzi z budynków, jak również możliwość zastosowania jej w tym opisie, ponieważ:

1) w celu rozpoczęcia ruchu nastąpić musi impuls do działania - w przypadku samochodów jest to najczęściej zmiana świateł sterujących ruchem, a w przypadku ludzi sygnał dźwiękowy lub komunikat głosowy sygnalizujący alarm pożarowy;

2) w zależności od gęstości pojazdów ich prędkość zmienia się, podobnie jest w przypadku przemieszczających się ludzi, gdy ich gęstość wzrasta, to prędkość maleje, i odwrotnie, gdy gęstości ludzi na drogach ewakuacyjnych maleje, to przemieszczający się ludzie z reguły przyspieszają;

3) tak jak pojazdy w ruchu drogowym tak ludzie wyprzedzają się, zderzają, omijają przeszkody, przyśpieszają na prostych odcinkach drogi, gdy ich gęstość jest mała oraz zwalniają, zwłaszcza przy zmianie kierunku ruchu;

4) tor przemieszczania się pojazdów i ewakuujących się z pożaru ludzi nie jest jednoznaczny. W obu przypadkach zależy od podejmowanych przez człowieka decyzji, jego zachowania są trudne do przewidzenia; 
5) moving vehicles and people evacuated from fire are influenced by a number of variables, such as people's behaviour, road conditions, people's decisions such as the choice of velocity, distance from other persons or obstacles, changes in road geometry, changes in direction of movement affecting velocity.

Vehicles in traffic, similar as people during evacuation, constantly interact with each other. Thus, in correspondence to the traffic theory, the state of the stream of moving people can be described with three variables:

1) people's movement intensity $F_{d}$ - the number of people passing through a specific section of the escape route in time, number of persons $/ \mathrm{m} \cdot \mathrm{s}$;

2 ) the density of evacuees $D$ is the number of people in an area of a specific section of the escape route, number of persons/sq. m;

3) average momentary velocity $\bar{v}_{\text {opt }}-$ the average velocity of people in motion, $\mathrm{m} / \mathrm{s}$.

\section{Proposal of an equation for estimating the evacuation time of people from public utility buildings ZL III}

In order to determine the evacuation time of people from a building, a model equation was derived (2), which, with an assumption that corresponds to the velocity of the evacuated person, specifies that people's evacuation time $T$ is equal to:

$$
T=\frac{\Delta x}{v \cdot \ln \left(\frac{k_{\max }}{k}\right)}
$$

where:

$T$ - people's evacuation time, $\mathrm{s}$;

$\Delta x$ - length of escape route, $\mathrm{m}$;

$v-$ velocity of an evacuated person, $\mathrm{m} / \mathrm{s}$;

$k_{\max }$ - maximum density of people on the escape route, congestion, number of persons/sq. m;

$k$ - density of people on the escape route, number of persons/sq. $m$.

Equation (2), forming a basis for the proposed proprietary computational model of evacuation time, was expanded with the following elements:

1) the entire escape route was divided into horizontal ( $x$ ) and vertical (y) sections, for which people's velocity is determined depending on their density according to table 1 [7] and equation (3):

$$
V_{s}=k-a \cdot k \cdot D
$$

where:

$V_{s}$ - velocity of a stream of people moving along a motion axis, $\mathrm{m} / \mathrm{s}$;

$D$ - density of people on the escape route's area, number of persons/sq. m;
5) na przemieszczające się pojazdy i ewakuujących się z pożaru ludzi wpływ ma wiele zmiennych, w tym: zachowanie się ludzi, warunki panujące na drogach, podejmowane decyzje np. dobór prędkości, odstępów od innych osób czy przeszkód, zmiany geometrii drogi, zmiany kierunku ruchu wpływające na prędkość poruszania się.

Pojazdy w ruchu drogowym, podobnie jak ludzie w trakcie ewakuacji, znajdują się w ciągłych wzajemnych interakcjach. Dlatego analogicznie do teorii ruchu drogowego, stan strumienia ruchu przemieszczających się ludzi określić można przez trzy zmienne:

1) intensywność przemieszczania się ludzi $F_{d}$ - liczba osób przechodzących przez określony przekrój drogi ewakuacyjnej w jednostce czasu, osoby/m · s;

2) gęstość ewakuujących się ludzi $D$ jest to liczba osób znajdujących się na powierzchni odcinka drogi ewakuacyjnej, osoby $/ \mathrm{m}^{2}$;

3) średnią prędkość chwilową $\bar{v}_{\text {opt }}$ - średnia prędkość poruszających się ludzi, m/s.

\section{Propozycja równania do szacowania czasu ewakuacji ludzi z budynków użyteczności publicznej ZL III}

W celu wyznaczenia czasu ewakuacji ludzi z budynku wyprowadzono równanie modelowe (2), które - przy założeniu, że odpowiada prędkości ewakuującej się osoby - określa, że czas ewakuacji ludzi $T$ wynosi:

$$
T=\frac{\Delta x}{v \cdot \ln \left(\frac{k_{\max }}{k}\right)}
$$

gdzie:

$T$ - czas ewakuacji ludzi, s;

$\Delta x$ - długość drogi ewakuacyjnej, m;

$v \quad$ - prędkość przemieszczenia się ewakuującej się osoby, m/s;

$k_{\max }$ - maksymalna gęstość ludzi na drodze ewakuacyjnej, powstanie zatoru, osoby/m²;

$k$ - gęstość ludzi na drodze ewakuacyjnej, osoby $/ \mathrm{m}^{2}$.

Równanie (2) stanowiące bazę zaproponowanego własnego modelu obliczeniowego czasu ewakuacji rozbudowano o następujące elementy:

1) całą drogę ewakuacyjną podzielono na poziome $x$ i pionowe y odcinki drogi, dla których wyznacza się prędkość przemieszczania się ludzi, zależnie od ich zagęszczenia zgodnie z tabelą 1 [7] i równaniem (3):

$$
V_{s}=k-a \cdot k \cdot D
$$

gdzie:

$V_{s}$ - prędkość strumienia przemieszczających się ludzi wzdłuż osi ruchu, m/s;

$D$ - gęstość ludzi na powierzchni drogi ewakuacyjnej, osoby $/ \mathrm{m}^{2}$; 
$k$ - the coefficient of motion along the escape route, $\mathrm{m} / \mathrm{s}$;

a - coefficient equal to $0.266 \mathrm{sq}$. $\mathrm{m} /$ persons.

2) the model assumption was that evacuation is carried out with an average density of all people present in a given section of the escape route. Local people's density values may in fact differ from waverage values;

3 ) the concept of replacement length was introduced for selected escape route sections in which the evacuation process is disrupted, which results in its extended duration. Such sections include:

a) local escape route pinch points caused by doors or structural elements.

b) change in direction of movement on a horizontal escape route (a turn at the corridor),

c) change in direction of movement during people's movement along a staircase (landings).

The concept of the replacement length of the aforementioned local disruptions along the escape route are presented in figure 1. k - współczynnik przemieszczania się po drodze ewakuacyjnej, m/s;

a - współczynnik równy $0,266, \mathrm{~m}^{2} /$ osoby.

2) założono modelowo, że ewakuacja odbywa się ze średnią gęstością wszystkich ludzi znajdujących się na danym odcinku drogi ewakuacyjnej. W rzeczywistości wartości lokalnej gęstości ludzi mogą się różnić od wartości średniej;

3) wprowadzono koncepcję długości zastępczej dla wybranych elementów drogi ewakuacyjnej, na których występują zakłócenia przebiegu procesu ewakuacji powodujące jej wydłużenie.

Do takich elementów drogi ewakuacyjnej należą:

a) lokalne zwężenia drogi ewakuacyjnej wynikające z występujących na drodze drzwi lub elementów konstrukcyjnych,

b) zmiana kierunku ruchu na poziomej drodze ewakuacyjnej (zakręt na korytarzu),

c) zmiana kierunku ruchu podczas przemieszczania się ludzi w obrębie klatki schodowej (spoczniki).

Koncepcję długości zastępczej wyżej wymienionych lokalnych zakłóceń na drodze ewakuacyjnej przedstawiono na rycinie 1.

Table 1. The value of constant $k$ in equation (3) for various elements of the escape route [7]

Tabela 1. Wartość stałej k w równaniu (3) dla różnych elementów drogi ewakuacyjnej [7]

\begin{tabular}{|c|c|c|}
\hline \multicolumn{2}{|c|}{ Elements of the escape route / Elementy drogi ewakuacyjnej } & $k$ \\
\hline \multicolumn{2}{|c|}{ Corridor / Korytarz } & 1 \\
\hline \multicolumn{2}{|c|}{ Staircase / Klatka schodowa } & \multirow{2}{*}{0} \\
\hline Stage height [mm] / Wysokość stopnia [mm] & Stage depth [mm] / Głębokość stopnia [mm] & \\
\hline 190.5 & 254.0 & 1.0 \\
\hline 177.8 & 279.4 & 1.08 \\
\hline 165.1 & 304.8 & 1.16 \\
\hline 165.1 & 330.2 & 1.23 \\
\hline
\end{tabular}

The idea of the replacement length of an escape route elements which impedes the motion of people is to replace each such element with a simple section with a length of $L z$ covered by evacuees in the same time as in the actual evacuation in the presence of an impeding element.

Below is the presentation of methods of calculating the replacement length of escape route elements which cause the slowing down of the evacuation process.

Pinch point of a horizontal escape route (doors, structural pinch points of the corridor)

The elements having an impact on the total evacuation time are pinch points found along the evacuation route, e.g. doors, narrow sections caused by obstacles such as elements of interior design, structural poles, etc.

In order to determine the replacement length of a pinch point of a horizontal escape route, the performed experiments were analysed and numerous computer simulations in the Pathfinder
Ideą długości zastępczej elementu drogi ewakuacyjnej, który spowalnia przemieszczanie się ludzi, jest zastąpienie każdego z takich elementów prostym odcinkiem o długości Lz pokonywanej przez ewakuujących się ludzi w takim samym czasie, w jakim przemieszczają się w rzeczywistej ewakuacji przy obecności elementu spowalniającego.

Poniżej przedstawiono metody obliczania długości zastępczej elementów drogi ewakuacyjnej, na których występuje lokalne spowolnienie procesu ewakuacji.

\section{Przewężenie drogi poziomej ewakuacyjnej (drzwi, przewężenia konstrukcyjne korytarza)}

Elementami, które wpływają na całkowity czas ewakuacji są występujące na drodze ewakuacyjnej przewężenia np. drzwi, wąskie odcinki spowodowane przez przeszkody w postaci elementów wystroju wnętrz, słupów konstrukcyjnych itp.

W celu wyznaczenia wartości długości zastępczej przewężenia poziomej drogi ewakuacyjnej analizie poddano przeprowadzone eksperymenty oraz wykonano szereg symulacji kompute- 


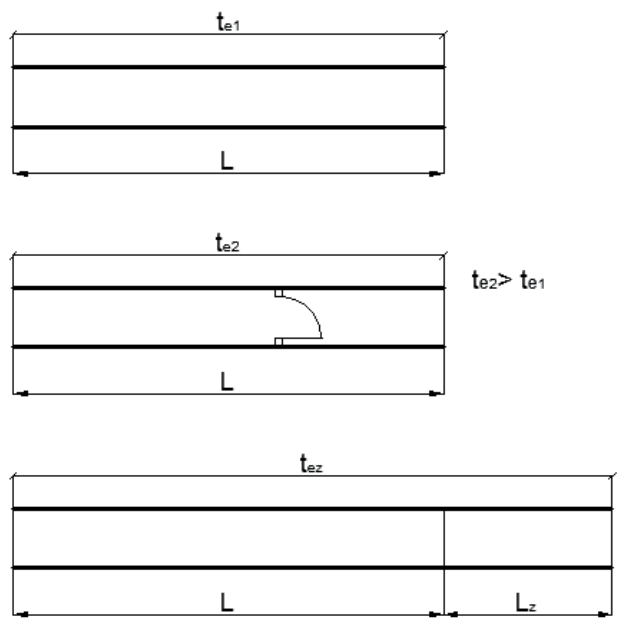

The fragment of a straight corridor of length $L$ with evacuation time $t_{\mathrm{el}}$

The fragment of a straight corridor of length $L$ with a local pinch point (e.g. door) with evacuation time $t_{\mathrm{e} 2}$.

The corridor of length $L$ with a local pinch point, substituted with length $L z$ of the same geometric properties. People's evacuation time along the corridor of length $L+L z$ is $t_{e 2}$ (which equals the real evacuation time along the corridor with a pinch point).

Figure 1. The Graphic Depiction of the Substitute Length Concept for the Obstructive Element impeding Human Evacuation Process Rycina 1. Schemat koncepcji długości zastępczej elementu zakłócającego przemieszczanie ewakuujących się ludzi Source: Own elaboration.

Źródło: Opracowanie własne.

software were carried out. After adopting certain simplifications of the studied issue, a statement was formulated that in the least favourable evacuation variant, i.e. a situation when before a local pinch point, as a result of a delay in launching evacuation, the highest accumulation of people occurs at a specific time.

In line with the assumption, the value of the replacement length of the pinch point on horizontal escape route $x_{0}$ is determined with equation (4):

$$
x_{o}=v_{x} \cdot \ln \left(\frac{k_{\max }}{k_{x}}\right) \cdot \frac{P}{F_{d} \cdot W}
$$

where:

$x_{o} \quad$ - replacement length of the pinch point on the horizontal escape route, $\mathrm{m}$;

$v_{x}$ - velocity of the evacuated people along the horizontal escape route, $\mathrm{m} / \mathrm{s}$;

$k_{\max }$ - maximum density of people on the escape route, congestion, number of persons/sq. m;

$k_{x}-$ density of people on the horizontal escape route, number of persons/sq. m;

$F_{d}$ - stream intensity, the number of evacuated people passing through a pinch point per metre of its effective width, number of persons $/ \mathrm{m} \cdot \mathrm{s}$;

$P \quad$ - the number of evacuees passing through the local pinch point, number of persons;

W - width of the local pinch point, $\mathrm{m}$.

\section{Change in direction of movement on a horizontal escape route} (a turn at the corridor)

Another element with an impact on the total evacuation time are changes in the direction of movement on a horizon- rowych w programie Pathfinder. Po założeniu pewnych uproszeń badanego zagadnienia określono, że dla najmniej korzystnego wariantu ewakuacji, to jest sytuacji, gdy przed lokalnym przewężeniem - na skutek opóźnień rozpoczęcia ewakuacji - tworzą się najliczniejsze na dany moment zgrupowania ludzi.

Zgodnie z założoną ideą wartość długości zastępczej przewężenia na poziomej drodze ewakuacyjnej $x_{0}$ jest wyznaczana zgodnie z równaniem (4):

$$
x_{o}=v_{x} \cdot \ln \left(\frac{k_{\max }}{k_{x}}\right) \cdot \frac{P}{F_{d} \cdot W}
$$

gdzie:

$x_{o} \quad$ - długość zastępcza przewężenia poziomej drogi ewakuacyjnej, $\mathrm{m}$;

$v_{x}$ - prędkość ewakuujących się osób po poziomej drodze ewakuacyjnej, m/s;

$k_{\max }$ - maksymalne zagęszczenie ludzi na drodze ewakuacyjnej, powstanie zatoru, osoby $/ \mathrm{m}^{2}$;

$k_{x}$ - zagęszczenie ludzi na poziomej drodze ewakuacyjnej, osoby/m²;

$F_{d}$ - intensywność strumienia, liczba ewakuujących się osób przez przewężenie na metr efektywnej jego szerokości, osoby $/ \mathrm{m} \cdot \mathrm{s}$;

$P$ - liczba osób ewakuujących się przez lokalne przewężenie, osoby;

W - szerokość lokalnego przewężenia, $\mathrm{m}$.

Zmiana kierunku ruchu na poziomej drodze ewakuacyjnej (np. zakręt na korytarzu)

Kolejnym elementem mającym wpływ na całkowity czas ewakuacji są zmiany kierunku ruchu na poziomej drodze ewa- 
tal escape route, i.e. corridor turns, flights of stairs where the evacuees naturally decrease their velocity, thus extending the evacuation time.

On the basis of the observations, the replacement length $x_{d}$ of the route with a change in the direction of movement at the meeting point of the stairs and the horizontal escape route and at a 90 degrees turn of the escape route it was assumed that it will amount to one fourth of the circumference of a circle with a radius of half the width of corridor $\mathrm{d}_{\mathrm{i}}$, in line with figure 2 and equation (5). kuacyjnej np. zakręty korytarzy, zejścia ze schodów, gdzie ewakuujący się ludzie podczas przemieszczania się w naturalny sposób zwalniają, a tym samym wydłużają czas ewakuacji.

Na podstawie przeprowadzonych obserwacji długość zastępczą $x_{d}$ drogi przy zmianie kierunku ruchu na styku schodów i poziomej drogi ewakuacyjnej oraz na zakręcie drogi ewakuacyjnej pod kątem $90^{\circ}$ przyjęto, że będzie ona wynosić jedną czwartą obwodu koła o promieniu połowy szerokości korytarza $\mathrm{d}_{\mathrm{i}} \mathrm{zgodnie}$ z ryciną 2 oraz równaniem (5). a)

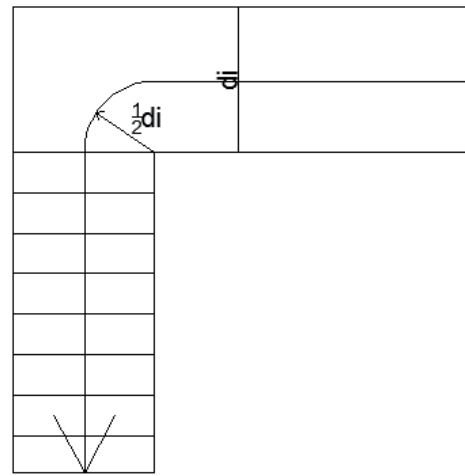

b)

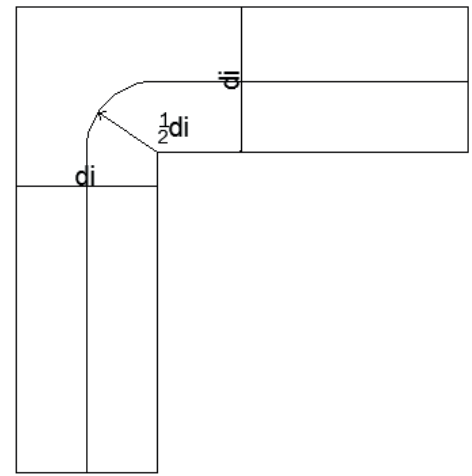

Figure 2. The picture shows: a) The change of movement direction, while switching from walking down the stairs to moving along the horizontal escape route; the analogous situation occurs when the evacuees go up the stairs. b) Change of movement direction within the corridor space Rycina 2. Zmiana kierunku ruchu: a) przy zejściu ze schodów na poziomą drogę ewakuacyjną (analogicznie przy wejściu na schody), b) w obrębie korytarza

Source: Own elaboration.

Źródło: Opracowanie własne.

In accordance with the adopted assumption, the replacement length of the route with a change in direction on the horizontal escape route is calculated in line with the following equation (5):

$$
x_{d}=\frac{\pi}{4} \cdot d_{i}
$$

where:

$x_{d}$ - replacement length of the route with a change in direction on the horizontal escape route, $\mathrm{m}$;

$d_{i}$ - the higher of the widths of escape routes at the confluence of which a change in the direction of movement occurs, $\mathrm{m}$. In the case of other geometry of the building, e.g. when a turn on a horizontal escape route takes the form of an arc, the replacement length of the route with such change in direction will equal the arc's length. Thus, each spatial arrangement of the analysed building should be considered separately.

Change in direction of movement during movement along a staircase (landings)

The replacement length of the route with a change in the direction of movement on horizontal escape route $y_{d}$ is determined for such locations as landings, where the velocity of evacuees
Zgodnie z przyjętym założeniem długość zastępczą drogi przy zmianie kierunku ruchu na poziomej drodze ewakuacyjnej oblicza się zgodnie z poniższym równaniem (5):

$$
x_{d}=\frac{\pi}{4} \cdot d_{i}
$$

gdzie:

$x_{d}$ - długość zastępcza drogi przy zmianie kierunku ruchu na poziomej drodze ewakuacyjnej, m;

$d_{i}$ - większaz szerokości dróg ewakuacyjnych, przyktórych zbiegu następuje zmiana kierunku ruchu, $\mathrm{m}$.

W przypadku innej geometrii budynku, np. gdy zakręt na poziomej drodze ewakuacyjnej występował będzie w postaci łuku, wartość długości zastępczej drogi przy takiej zmianie kierunku ruchu będzie równa długości łuku. Tak więc każdy układ przestrzenny analizowanego budynku należy rozpatrywać indywidualnie.

\section{Zmiana kierunku ruchu podczas przemieszczania się w obrębie} klatki schodowej (spoczniki)

Długość zastępcza drogi przy zmianie kierunku ruchu na pionowej drodze ewakuacyjnej $\mathrm{y}_{\mathrm{d}}$ wyznacza się dla miejsc takich jak spoczniki, gdzie prędkość ewakuujących się ludzi maleje pra- 
decreases almost twofold. The replacement length of the route with a change in the direction of movement on horizontal escape route $y_{d}$ is half the length of the circumference of a circle with a radius of half the width of the staircase on which people move, in line with figure 3 and equation (6).

In line with the adopted principle, the replacement length of the route with a change of direction on the vertical escape route along which people move is calculated in line with the following equation (6):

$$
y_{d}=\frac{\pi}{2} \cdot e_{i}
$$

where:

$y_{d}$ - replacement length of the route with a change in direction on the vertical escape route, $\mathrm{m}$; $e_{i}-$ width of the ith flight of stairs, $m$. wie dwukrotnie. Długość zastępcza drogi przy zmianie kierunku ruchu na pionowej drodze ewakuacyjnej $y_{d}$ wynosi połowę długości obwodu koła o promieniu połowy szerokości biegu klatki schodowej, po której przemieszczają się ludzie zgodnie z ryciną 3 oraz równaniem (6).

Zgodnie z przyjętą zasadą długość zastępczą drogi przy zmianie kierunku ruchu na pionowej drodze ewakuacyjnej, po której przemieszczają się ludzie, oblicza się zgodnie z poniższym równaniem (6):

$$
y_{d}=\frac{\pi}{2} \cdot e_{i}
$$

gdzie:

$y_{d}$ - długość zastępcza drogi przy zmianie kierunku ruchu na pionowej drodze ewakuacyjnej, $\mathrm{m}$;

$e_{i}$ - szerokość i-tego biegu schodów, m.

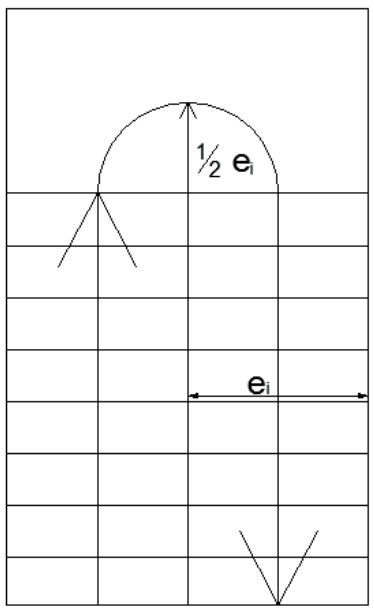

Figure 3. A typical representation of the landing of the stairs, where the evacuees progress along the circumference of a circle with the radius of half the width of flight of stairs ei

Rycina 3. Przykładowy widok spocznika klatki schodowej: przemieszczający się ludzie idą po obwodzie koła o promieniu połowy szerokości biegu klatki schodowej ei

Source: Own elaboration.

Źródło: Opracowanie własne.

\section{Proposal of a model equation for estimating the evacuation time} of people from public utility buildings

On the basis of the performed experiments and computer simulations an assumption was made to divide the escape route into horizontal and vertical sections depending on their density. Combined spaces (rooms with access to the corridor from which another space can be accessed, such as a staircase) with a permanent number of users are regarded as a single section of a horizontal escape route with one impeding element. Fire-rated vestibules in front of staircases and halls through which escape routes lead outside the building are also considered elements of vertical escape routes.

The proposed equation for determining the evacuation time (7) is a total passage time through horizontal and vertical escape routes increased with replacement length of the route
Zaproponowane równanie modelowe szacowania czasu ewakuacji ludzi z budynków użyteczności publicznej

Na podstawie wykonanych eksperymentów i symulacji komputerowych założono, że drogę ewakuacyjną dzielimy na odcinki poziomej i pionowej dróg ewakuacyjnych w zależności od tworzącego się na nich zagęszczenia Połączoe ze sobą pomieszczenia (pomieszczenia z wyjściem na korytarz, z którego można dostać się do innego pomieszczenia - np. klatki schodowej), ze stałą liczbą użytkowników traktowane są jako jeden odcinek poziomej drogi ewakuacyjnej z jednym elementem spowalniającym. Przedsionki przeciwpożarowe przed klatkami schodowymi oraz hole, przez które prowadzi droga ewakuacyjna na zewnątrz budynku, uznaje się jako elementy pionowej drogi ewakuacyjnej.

Zaproponowane równanie na wyznaczanie czasu ewakuacji (7) to suma czasu przejścia poziomymi i pionowymi drogami 
resulting from changing directions of movement and local obstacles found along the escape route (e.g. doors).

On the basis of the above assumptions, a general model was put forward to estimate people's evacuation time from buildings, which is a modified version of Greenberg's equation (1): ewakuacyjnymi powiększonymi o długości zastępcze drogi wynikające ze zmiany kierunków ruchu oraz lokalnych utrudnień występujących na drodze ewakuacji (np. drzwi).

Na podstawie powyższych założeń zaproponowano ogólny model do szacowania czasu ewakuacji ludzi z budynków, będący modyfikacją równania Greenberga (1):

$$
T=\frac{1}{v_{x_{l}}} \cdot \sum_{l=1}^{m} \frac{1}{\ln \left(\frac{k_{\max }}{k_{x_{l}}}\right)} \cdot\left(x_{l}+\sum_{\mathrm{i}=1}^{\mathrm{n}} \mathrm{x}_{\mathrm{d}_{\mathrm{i}}}+\sum_{\mathrm{i}=1}^{\mathrm{f}} \mathrm{x}_{\mathrm{o}_{\mathrm{i}}}\right)+\frac{1}{v_{y_{l}}} \cdot \sum_{l=1}^{g} \frac{1}{\ln \left(\frac{k_{\max }}{k_{y_{l}}}\right)} \cdot\left(y_{l}+\sum_{\mathrm{i}=1}^{\mathrm{h}} \mathrm{y}_{\mathrm{d}_{\mathrm{i}}}+\sum_{\mathrm{i}=1}^{\mathrm{e}} \mathrm{x}_{\mathrm{c}_{\mathrm{i}}}\right)
$$

where:

$\mathrm{T}$ - passage time of people during evacuation from the moment until exiting the building or the neighbouring fire zone, s;

$v_{x_{l}}-$ velocity of people moving along the Ith horizontal escape route, I $=1, \ldots, \mathrm{m}, \mathrm{m} / \mathrm{s}$;

m - the number of horizontal sections of escape routes, -;

$x_{l}$ - length of the Ith horizontal escape route, $\mathrm{I}=1, \ldots, \mathrm{m}, \mathrm{m}$;

$\mathrm{k}_{\max }$ - maximum density of people on the escape route, congestion, number of persons/sq. m;

$k_{x}$-density of people on the Ith horizontal escape route, $\mathrm{I}=1, \ldots, \mathrm{m}$, number of persons $/ \mathrm{sq} . \mathrm{m}$,

$\mathrm{n}$ - number of movement direction changes on the lth horizontal escape route, $\mathrm{I}=1, \ldots, \mathrm{m},-$;

$\mathrm{x}_{\mathrm{d}_{\mathrm{i}}}$ - replacement length of the route with a change in direction on the Ith horizontal escape route, $I=1, \ldots, m, i=1, \ldots, n, m$;

$f-$ number of pinch points on the lth horizontal escape route, $\mathrm{I}=1, \ldots, \mathrm{m},-;$

$\mathrm{x}_{\mathrm{o}_{\mathrm{i}}}$ - replacement length of the pinch point on the Ith horizontal escape route, $\mathrm{I}=1, \ldots, \mathrm{m}, \mathrm{i}=1, \ldots, \mathrm{f}, \mathrm{m}$;

$v_{l}$ - velocity of people moving along the Ith vertical escape route, $\mathrm{I}=1, \ldots, \mathrm{g}, \mathrm{m} / \mathrm{s}$;

$g$ - the number of vertical sections of escape routes, -;

$k_{y}$-density of people on the Ith vertical escape route,

$y_{l} \quad \mathrm{I}=1, \ldots, \mathrm{m}$, number of persons / sq. $\mathrm{m}$,

$y_{1} \quad$ - length of the Ith vertical escape route, $I=1, \ldots, g, m$;

$\mathrm{h}$ - number of movement direction changes on the Ith vertical escape route, $\mathrm{I}=1, \ldots, \mathrm{g},-$;

$\mathrm{y}_{\mathrm{d}_{\mathrm{i}}}$ - replacement length of the route with a change in direction on the Ith vertical escape route, $I=1, \ldots, g, m$;

e - number of pinch points on the Ith vertical escape route, $\mathrm{I}=1, \ldots, \mathrm{g},-$;

$x_{c_{i}}$ - replacement length of the pinch point on the Ith vertical escape route, $\mathrm{I}=1, \ldots, \mathrm{g}, \mathrm{i}=1, \ldots, \mathrm{e}, \mathrm{m}$;

In line with literature data [9] the assumption made in the model put forward was that the density of evacuees [person/ sq. $\mathrm{m}$ ] at which the movement stops $\left(\mathrm{k}_{\max }\right)$ is 5 people per sq. $\mathrm{m}$. The velocity on horizontal and vertical sections of escape routes should be calculated with equation (2). gdzie:

T - czas przejścia ludzi podczas ewakuacji od momentu rozpoczęcia ruchu do momentu wyjścia na zewnątrz budynku lub sąsiedniej strefy pożarowej, s;

$v_{x_{l}}$ - prędkość przemieszczających się osób na l-tej poziomej drodze ewakuacyjnej, I = 1,..., m, m/s;

m - liczba poziomych odcinków dróg ewakuacyjnych, -;

$x_{I}$ - długość l-tej poziomej drogi ewakuacyjnej, I = 1,..., m, m;

$\mathrm{k}_{\max }$ - maksymalne zagęszczenie ludzi na drodze ewakuacyjnej, powstanie zatoru, osoby/m²;

$k_{x}$ - zagęszczenie ludzi na l-tej poziomej drodze ewakuacyjnej, $\mathrm{I}=1, \ldots, \mathrm{m}$, osoby $/ \mathrm{m}^{2}$,

n - liczba zmian kierunków ruchu na l-tej poziomej drodze ewakuacyjnej, I = 1,..., m, -;

$\mathrm{x}_{\mathrm{d}_{\mathrm{i}}}$ - długość zastępcza drogi przy zmianie kierunku ruchu na I-tej poziomej drodze ewakuacyjnej, I = 1,..., m, i = 1, .., n, m;

f - liczba przewężeń występujących na l-tej poziomej drodze ewakuacyjnej, I = 1,...,m, -;

$\mathrm{x}_{\mathrm{o}_{\mathrm{i}}}$ - długość zastępcza przewężenia na l-tej poziomej drodze ewakuacyjnej, l=1,...,m, i = 1, ..., f, m;

$v_{y_{l}}$ - prędkość przemieszczających się osób na l-tej pionowej drodze ewakuacyjnej, I = 1,..,g, m/s;

$g$ - liczba pionowych odcinków dróg ewakuacyjnych, -;

$k_{y}$ - zagęszczenie ludzi na I-tej pionowej drodze ewakuacyjnej, $\mathrm{I}=1, \ldots, \mathrm{m}$, osoby $/ \mathrm{m}^{2}$;

$y_{1} \quad$-długość l-tej pionowej drogi ewakuacyjnych, I = 1,..,g, m;

h - liczba zmian kierunków ruchu na l-tej pionowej drodze ewakuacyjnej, I = 1,...,g, -;

$\mathrm{y}_{\mathrm{d}_{\mathrm{i}}}$ - długość zastępcza drogi przy zmianie kierunku ruchu na I-tej pionowej drodze ewakuacyjnej, I = 1,...,g, m;

e - liczba przewężeń występujących na l-tej pionowej drodze ewakuacyjnej, I = 1,...,g, -;

$\mathrm{x}_{\mathrm{c}_{\mathrm{i}}}$ - długość zastępcza przewężenia na l-tej pionowej drodze ewakuacyjnej, $\mathrm{I}=1, \ldots, \mathrm{g}, \mathrm{i}=1, \ldots, \mathrm{e}, \mathrm{m}$;

Zgodnie z danymi literaturowymi [9] w zaproponowanym modelu przyjęto, że gęstość ewakuujących się ludzi [osoba/m²], przy której następuje zatrzymanie ruchu $\mathrm{k}_{\max }$ wynosi 5 osób/m². Prędkość na poziomych i pionowych odcinkach dróg ewakuacyjnych należy wyznaczyć zgodnie z równaniem (2). 


\section{Comparison of the evacuation times obtained with the proposed model equation with times of experimental evacuations and computer simulations}

In order to verify the accuracy of estimation of the evacuation time of people from public utility buildings with the model put forward, the evacuation times derived from the model were compared with experimental times obtained from tests performed during the evacuation of the following buildings: the Industrial Chemistry Research Institute in Warsaw, TVP (Polish Television) in Łódź, Marshal's Office in Łódź, the District Fire Department Headquarters in Pabianice and independent evacuation carried out in one of Wrocław's high-rise buildings (with results presented in table 2 with determining deviation from the performed practice evacuations [2], [10].

\section{Porównanie otrzymanych czasów ewakuacji za pomocą zaproponowanego modelowego równania z czasami przeprowadzonych eksperymentalnie ewakuacji oraz symulacjami komputerowymi}

W celu sprawdzenia poprawności szacowania czasu ewakuacji ludzi z budynków użyteczności publicznej przy zastosowaniu zaproponowanego modelu, otrzymane za jego pomocą czasy ewakuacji porównano z czasami eksperymentalnymi, uzyskanymi podczas badań przeprowadzonych podczas ewakuaci z budynków: Instytutu Chemii Przemysłowej w Warszawie, TVP w Łodzi, Urzędu Marszałkowskiego w Łodzi, Komendy Powiatowej PSP w Pabianicach i niezależnej ewakuacji przeprowadzonej w jednym z wrocławskich budynków wysokościowych (co przedstawiono w tabeli 2 wraz z określeniem wielkości odchylenia wyniku w stosunku do przeprowadzonych prób ewakuacji) [2], [10].

Table 2. The juxtaposition of results obtained during real-life evacuation testing and the results obtained theoretically

Tabela 2. Zestawienie czasów uzyskanych podczas badań z czasami ewakuacji obliczonymi za pomocą zaproponowanego równania

\begin{tabular}{|c|c|c|c|}
\hline \multirow[t]{2}{*}{$\begin{array}{l}\text { Location of the experiment } \\
\text { Miejsce eksperymentu }\end{array}$} & \multirow[t]{2}{*}{$\begin{array}{c}\text { Evacuation time } \\
\text { Czas ewakuacji - eksperymenty }\end{array}$} & \multicolumn{2}{|c|}{$\begin{array}{l}\text { Evacuation time calculated from the proposed equation (7) } \\
\text { Czas ewakuacji obliczony z zaproponowanego równania (7) }\end{array}$} \\
\hline & & $\begin{array}{l}\text { Evacuation time }[\mathbf{s}] \\
\text { Czas ewakuacji [s] }\end{array}$ & $\begin{array}{l}\text { Time value discrepancy [\%] } \\
\text { Odchylenie wyniku [\%] }\end{array}$ \\
\hline $\begin{array}{l}\text { Industrial Chemistry in Warsaw (experiment 1) } \\
\text { Instytut Chemii Przemysłowej (eksperyment 1) }\end{array}$ & 67.0 & 62.8 & -6.2 \\
\hline $\begin{array}{l}\text { Industrial Chemistry in Warsaw (experiment 2) } \\
\text { Instytut Chemii Przemysłowej (eksperyment 2) }\end{array}$ & 61.0 & 68.1 & +11.7 \\
\hline $\begin{array}{l}\text { Industrial Chemistry in Warsaw (experiment 3) } \\
\text { Instytut Chemii Przemysłowej (eksperyment 3) }\end{array}$ & 60.0 & 85.8 & +42.6 \\
\hline $\begin{array}{l}\text { Industrial Chemistry in Warsaw (experiment 4) } \\
\text { Instytut Chemii Przemysłowej (eksperyment 4) }\end{array}$ & 51.0 & 94.0 & +84.4 \\
\hline $\begin{array}{l}\text { Public Television Building in Lodz } \\
\text { Budynek TVP w Łodzi }\end{array}$ & 292.0 & 446.5 & +52.9 \\
\hline $\begin{array}{l}\text { The Marshall's Office Building in Lodz } \\
\text { Urząd Marszałkowski w Łodzi }\end{array}$ & 434.0 & 279.1 & -35.7 \\
\hline $\begin{array}{l}\text { The District Fire Department Headquarters in Pabianice } \\
\text { KP PSP Pabianice }\end{array}$ & 41.5 & 26.8 & -35.4 \\
\hline $\begin{array}{l}\text { Wroclaw's tower } \\
\text { Budynek wysokościowy we Wrocławiu }\end{array}$ & 1260 & 882.5 & -30.0 \\
\hline
\end{tabular}

Source: Own elaboration

Źródło: Opracowanie własne.

Analysing the results of computations presented in table 2 , it must be concluded that despite many simplifying assumptions made in the proposed model arising from the complexity of the evacuation process, the accuracy of the description of experimental data achieved with the model put forward is satisfactory. The largest computational errors of the proposed model concerned cases in which the density of evacuees was very low,
Analizując wyniki obliczeń przedstawione w tabeli 2, należy stwierdzić, że mimo poczynionych $w$ zaproponowanym modelu wielu założeń upraszczających, wynikających ze złożoności procesu ewakuacji ludzi, dokładność opisu danych doświadczalnych za pomocą zaproponowanego modelu jest zadowalająca. Największe błędy obliczeniowe zaproponowanego modelu dotyczyły przypadków, w których gęstość ewakuujących się ludzi była 
below 0.2 person per sq. $m$ on a vertical escape route. A similar situation was observed for a high density of people above 2.5 person per sq. $\mathrm{m}$. The highest bias of as many as $+84.4 \%$ was observed during the experiment in which the initial density of evacuees was 4 persons per sq. m. Such a large bias results from using the original form of Greenberg's model, which was the basis for the proposed model for the evacuation of people which makes use of the analogy method. In that model, the velocity of evacuees depends on their density. Thus, the general principle was confirmed that even for the original Greenberg's model [3] the highest bias in the description of vehicles' motion occurs with the highest and lowest traffic densities.

In addition, there is a major controversy in the literature regarding velocity values of people moving along horizontal and vertical escape routes for the highest and lowest densities of evacuees, which has an impact on the accuracy of the computed evacuation time models.

In order to improve the accuracy of calculations of evacuation time obtained from the proposed model with a number of simplifying assumptions as compared to the actual stochastic evacuation process, adjustment coefficient A was introduced. Thus, the modified form of the model takes the form of equation (8): bardzo mała i wynosiła poniżej 0,2 osoby $/ \mathrm{m}^{2}$ na pionowej drodze ewakuacyjnej. Podobna sytuacja miała miejsce w przypadku dużego zagęszczenia ludzi wynoszącego powyżej 2,5 osoby/m². Największy błąd - aż $+84,4$ \% - uzyskano podczas eksperymentu, w którym początkowa gęstość ewakuujących się ludzi wynosiła 4 osoby/m². Tak duży błąd wynika oczywiście z zastosowania oryginalnej postaci oryginalnego modelu Greenberga, który był podstawą do opracowania zaproponowanego modelu ewakuacji ludzi wykorzystującego metodę analogii. W modelu tym prędkość ewakuujących się ludzi jest uzależniona od ich gęstości. Potwierdzona została więc ogólna zasada, która mówi, że nawet dla oryginalnego modelu Greenberga [3] największy błąd opisu przemieszczania się pojazdów występuje dla ich największych i najmniejszych gęstości na drodze.

Dodatkowo duże kontrowersje w literaturze budzą wartości prędkości przemieszczających się ludzi po poziomych i pionowych drogach ewakuacyjnych dla największych i najmniejszych gęstości ewakuujących się osób, co ma wpływ na dokładność obliczanych modelowych czasów ewakuacji.

W celu poprawy dokładności obliczeń czasu ewakuacji otrzymywanych z zaproponowanego modelu zakładającego wiele założeń upraszczających w stosunku do rzeczywistego, stochastycznego procesu ewakuacji wprowadzono współczynnik korekcyjny A. Zmodyfikowana postać modelu przyjmuje ma więc postać równania (8):

$$
T=\frac{1}{v} x_{l} \quad \sum_{l=1}^{m} \frac{1}{\ln \left(\frac{k_{\max }}{k_{x_{l}}}\right)} \cdot\left(A \cdot x_{l}+A \cdot \sum_{\mathrm{i}=1}^{\mathrm{n}} \mathrm{x}_{\mathrm{d}_{\mathrm{i}}}+\sum_{\mathrm{i}=1}^{\mathrm{f}} \mathrm{x}_{\mathrm{o}_{\mathrm{i}}}\right)+\frac{1}{v_{y_{l}}} \cdot \sum_{l=1}^{g} \frac{1}{\ln \left(\frac{k_{\max }}{k_{y_{l}}}\right)} \cdot\left(A \cdot y_{l}+A \cdot \sum_{\mathrm{i}=1}^{\mathrm{h}} \mathrm{y}_{\mathrm{d}_{\mathrm{i}}}+\sum_{\mathrm{i}=1}^{\mathrm{e}} \mathrm{x}_{\mathrm{c}_{\mathrm{i}}}\right)
$$

where:

$T$ - passage time of people during evacuation from the moment until exiting the building or the neighbouring fire zone, s;

$v_{x_{l}}-$ velocity of people moving along the Ith horizontal escape route, $\mathrm{I}=1, \ldots, \mathrm{m}, \mathrm{m} / \mathrm{s}$;

$m$ - the number of horizontal sections of escape routes, -;

A - adjustment coefficient, -;

$x_{I} \quad$ - length of the Ith horizontal escape route, $\mathrm{I}=1, \ldots, \mathrm{m}, \mathrm{m}$;

$k_{\max }$ - maximum density of people on the escape route, congestion, number of persons/sq. m;

$k_{x}$ - density of people on the Ith horizontal escape route, $\mathrm{I}=1$,

${ }^{l} \quad$..., m, number of persons / sq. m;

$n$ - number of movement direction changes on the Ith horizontal escape route, $\mathrm{I}=1, \ldots, \mathrm{m},-;$

$\mathrm{x}_{\mathrm{O}_{\mathrm{i}}}$ - replacement length of the route with a change in direction on the Ith horizontal escape route, $I=1, \ldots, \mathrm{m}, \mathrm{i}=1, \ldots, \mathrm{n}, \mathrm{m}$;

$f$ - number of pinch points on the lth horizontal escape route, $\mathrm{I}=1, \ldots, \mathrm{m},-$;

$\mathrm{x}_{\mathrm{o}_{\mathrm{i}}}$ - replacement length of the pinch point on the Ith horizontal escape route, $\mathrm{I}=1, \ldots, \mathrm{m}, \mathrm{i}=1, \ldots, \mathrm{f}, \mathrm{m}$;

$v_{y_{l}}$ - velocity of people moving along the lth vertical escape route, $\mathrm{I}=1, \ldots, \mathrm{g}, \mathrm{m} / \mathrm{s}$;

$g$ - the number of vertical sections of escape routes, -; gdzie:

$T$ - czas przejścia ludzi podczas ewakuacji od momentu rozpoczęcia ruchu do momentu wyjścia na zewnątrz budynku lub sąsiedniej strefy pożarowej, s;

$v_{x_{l}}-$ prędkość przemieszczających się osób na l-tej poziomej drodze ewakuacyjnej, I = 1,..., m, m/s;

$m$ - liczba poziomych odcinków dróg ewakuacyjnych, -;

A - współczynnik korekcyjny, -;

$x_{I} \quad$-długość l-tej poziomej drogi ewakuacyjnej, I = 1,..., m, m;

$k_{\max }$ - maksymalne zagęszczenie ludzi na drodze ewakuacyjnej, powstanie zatoru, osoby/ $\mathrm{m}^{2}$;

$k_{x}$ - zagęszczenie ludzi na I-tej poziomej drodze ewakuacyjnej,

${ }^{l} l \quad \mathrm{I}=1, \ldots, \mathrm{m}$ osoby $/ \mathrm{m}^{2}$;

$n \quad$ - liczba zmian kierunków ruchu na l-tej poziomej drodze ewakuacyjnej, $\mathrm{I}=1, \ldots, \mathrm{m},-$;

$\mathrm{x}_{\mathrm{o}_{\mathrm{i}}}$ - długość zastępcza drogi przy zmianie kierunku ruchu na I-tej poziomej drodze ewakuacyjnej, I = 1,.., m, i = 1, ..., n, m;

$f \quad$ - liczba przewężeń występujących na l-tej poziomej drodze ewakuacyjnej, I = 1,...,m, -;

$\mathrm{x}_{\mathrm{o}_{\mathrm{i}}}$ - długość zastępcza przewężenia na l-tej poziomej drodze ewakuacyjnej, I = 1,...,m, i = 1, ..., f, m;

$v_{y_{l}}$ - prędkość przemieszczających się osób na l-tej pionowej drodze ewakuacyjnej, I = 1,...,g, m/s;

$g$ - liczba pionowych odcinków dróg ewakuacyjnych, -; 
$k_{y}$ - density of people on the Ith vertical escape route, $\mathrm{I}=$

$y_{l} \quad 1, \ldots, \mathrm{m}$, number of persons / sq. $\mathrm{m}$,

$y_{1}$ - length of the lth vertical escape route, $I=1, \ldots, \mathrm{g}, \mathrm{m}$;

$h$ - number of movement direction changes on the Ith vertical escape route, $\mathrm{I}=1, \ldots, \mathrm{g},-$;

$y_{d_{i}}$ - replacement length of the route with a change in direction on the Ith vertical escape route, $\mathrm{I}=1, \ldots, \mathrm{g}, \mathrm{m}$;

$e-$ number of pinch points on the lth vertical escape route, $\mathrm{I}=1, \ldots, \mathrm{g},-$;

$x_{c_{i}}$ - replacement length of the pinch point on the lth vertical escape route, $\mathrm{I}=1, \ldots, \mathrm{g}, \mathrm{i}=1, \ldots, \mathrm{e}, \mathrm{m}$.

Adjustment coefficient $A$, as a result of the analysis of experimental data, assumed the following values for a horizontal escape route:

$$
\begin{array}{ll}
\text { for } 0.3 \leq k_{x_{i}}<0.8 & A=1.7 \\
\text { for } 0.8 \leq k_{x_{i}}<2.5 & A=1,2 ; \\
\text { for } 2.5 \leq k_{x_{i}}<3.2 & A=0.4 .
\end{array}
$$

Adjustment coefficient $A$, as a result of the analysis of experimental data, assumed the following values for a vertical escape route:

$$
\begin{aligned}
& \text { for } 0.3 \leq k_{y_{1}}<0.8 \quad A=1.7 \\
& \text { for } 0.8 \leq k_{y_{1}}<1 \quad A=1,2 \\
& \text { for } 1 \leq k_{y_{1}}<2.2 \quad A=0.7 \\
& \text { for } 2.2 \leq k_{y_{1}}<3.2 \quad A=0.4
\end{aligned}
$$

$k_{y}$ - zagęszczenie ludzi na l-tej pionowej drodze ewakuacyjnej, $y_{l} \quad \mathrm{I}=1, \ldots, \mathrm{m}$ osoby/m²;

$y_{1}$ - długość l-tej pionowej drogi ewakuacyjnych, I = 1,...,g, m;

$h$ - liczba zmian kierunków ruchu na l-tej pionowej drodze ewakuacyjnej, I = 1,...,g, -;

$\mathrm{y}_{\mathrm{d}_{\mathrm{i}}}-$ długość zastępcza drogi przy zmianie kierunku ruchu na I-tej pionowej drodze ewakuacyjnej, I = 1,...,g, m;

e - liczba przewężeń występujących na l-tej pionowej drodze ewakuacyjnej, I = 1,...,g, --

$\mathrm{x}_{\mathrm{c}_{\mathrm{i}}}$ - długość zastępcza przewężenia na l-tej pionowej drodze ewakuacyjnej, $\mathrm{I}=1, \ldots, \mathrm{g}, \mathrm{i}=1, \ldots, \mathrm{e}, \mathrm{m}$.

Współczynnik korekcyjny A w wyniku analizy danych doświadczalnych przyjmuje następujące wartości dla poziomej drogi ewakuacyjnej:

$$
\begin{array}{ll}
\text { dla } 0,3 \leq k_{x_{i}}<0,8 & \text { wartość } A=1,7 ; \\
\text { dla } 0,8 \leq k_{x_{i}}<2,5 & \text { wartość } A=1,2 ; \\
\text { dla } 2,5 \leq k_{x_{i}}<3,2 & \text { wartość } A=0,4 .
\end{array}
$$

\begin{tabular}{|c|c|c|c|}
\hline \multirow[t]{2}{*}{$\begin{array}{l}\text { Location of the experiment } \\
\text { Miejsce eksperymentu }\end{array}$} & \multirow[t]{2}{*}{$\begin{array}{l}\text { Evacuation time } \\
\text { experiments [s] } \\
\text { Czas ewakuacji } \\
\text { - eksperymenty [s] }\end{array}$} & \multicolumn{2}{|c|}{$\begin{array}{c}\text { Equation use estimate of evacuation time (8) } \\
\text { Czas ewakuacji obliczony } \\
\text { z zaproponowanego równania (8) }\end{array}$} \\
\hline & & $\begin{array}{l}\text { Evacuation time }[\mathbf{s}] \\
\text { Czas ewakuacji }[\mathbf{s}]\end{array}$ & $\begin{array}{l}\text { Time value discrepancy [\%] } \\
\text { Odchylenie wyniku [\%] }\end{array}$ \\
\hline $\begin{array}{l}\text { Industrial Chemistry in Warsaw (experiment 1) } \\
\text { Instytut Chemii Przemysłowej (eksperyment 1) }\end{array}$ & 67.0 & 72.0 & +7.5 \\
\hline $\begin{array}{l}\text { Industrial Chemistry in Warsaw (experiment 2) } \\
\text { Instytut Chemii Przemysłowej (eksperyment 2) }\end{array}$ & 61.0 & 63.0 & +3.3 \\
\hline $\begin{array}{l}\text { Industrial Chemistry in Warsaw (experiment 3) } \\
\text { Instytut Chemii Przemysłowej (eksperyment 3) }\end{array}$ & 60.0 & 64.9 & +8.2 \\
\hline $\begin{array}{l}\text { Industrial Chemistry in Warsaw (experiment 4) } \\
\text { Instytut Chemii Przemysłowej (eksperyment 4) }\end{array}$ & 51.0 & 55.3 & +8.4 \\
\hline $\begin{array}{l}\text { Public Television Building in Lodz } \\
\text { Budynek TVP w Łodzi }\end{array}$ & 292.0 & 320.3 & +9.7 \\
\hline $\begin{array}{l}\text { The Marshall's Office Building in Lodz } \\
\text { Urząd Marszałkowski w Łodzi }\end{array}$ & 434.0 & 380.6 & 12.3 \\
\hline $\begin{array}{l}\text { The District Fire Department Headquarters in Pabianice } \\
\text { KP PSP Pabianice }\end{array}$ & 41.5 & 47.2 & +13.8 \\
\hline $\begin{array}{l}\text { Wroclaw's tower } \\
\text { Budynek wysokościowy we Wrocławiu }\end{array}$ & 1260 & 1114.8 & 11.5 \\
\hline
\end{tabular}

Współczynnik korekcyjny A w wyniku analizy danych doświadczalnych przyjmuje następujące wartości dla pionowej drogi ewakuacyjnej:

$$
\begin{aligned}
& \text { dla } 0,3 \leq k_{y_{1}<0,8} \text { wartość } A=1,7 ; \\
& \text { dla } 0,8 \leq k_{y_{1}<1} \text { wartość } A=1,2 ; \\
& \text { dla } 1 \leq k_{y_{1}}<2,2 \text { wartość } A=0,7 ; \\
& \text { dla } 2,2 \leq k_{y_{1}}<3,2 \text { wartość } A=0,4 .
\end{aligned}
$$

Table 3. The juxtaposition of results obtained during real-life evacuation testing and the results obtained theoretically

Tabela 3. Zestawienie czasów uzyskanych podczas badań z czasami ewakuacji obliczonymi za pomocą zaproponowanego równania

Source: Own elaboration.

Źródło: Opracowanie własne. 
The model can be applied for a density of people on escape routes from 0.3 to 3.2 persons per sq. $\mathrm{m}$. The value results from literature data [7] and proprietary experimental data. This range covers a considerable majority of real evacuations of people from buildings. After the inclusion of the adjustment coefficient A values mentioned above in the proposed model (8), table 3 contains a comparison of experimental times and those calculated on the basis of the modified model.

The analysis of the results included in table 3 makes it possible to state that the evacuation times calculated from the modified model put forward (8) are subject to a bias ranging from $-12.3 \%$ to $+13.8 \%$ as compared to the experimental times. This forms a basis for a conclusion that the proposed equation (8) for calculating evacuation times of people from buildings gives very similar results to those obtained in real experiments carried out for the purposes of this study. The comparisons confirmed that equation (8) is suitable for calculating evacuation times for building with varying geometries and number of users. Most importantly, also in comparison with an independent research performed in one of high-rise public utility and residential buildings (evacuation of 286 people from storey +49 and 50 ), the deviation of the evacuation time computed from the model was subject to a $-11.5 \%$ bias. In most cases the obtained evacuation times are slightly overestimated, which is favourable from the fire protection perspective.

Equation (8) also provides a good description of experimental data even in cases very rarely occurring in practice, when the density of evacuees is very low, below 0.3 person per sq. on horizontal escape routes and 0.2 person per sq. $\mathrm{m}$. on vertical routes. In such case the value of adjustment coefficient $A$ is 5. However, in very rare cases of a very high density of evacuated people higher than 3 persons per sq. $\mathrm{m}$ on a horizontal escape route, adjustment coefficient $A$ is 0.3 , and for a vertical escape route with a density exceeding 3.2 persons per sq. $\mathrm{m}$ it amounts 0.1. However, this was confirmed for few experimental data. Thus, the model proposed in the study was confirmed for numerous evacuation situations for densities of evacuees from 0.3 to 3.2 persons per sq. $\mathrm{m}$.

Based to the above, it can be assumed that equation (8) is a universal tool possible to be applied for determining evacuation times of people from various ZL III public utility buildings with satisfactory accuracy.

For the additional verification of the proposed model equation (8) as suitable for determining the evacuation time of people, a series of computer simulations was carried out with the Pathfinder software applying the variable-control model. Computer simulations were performed for 20 various geometries of public utility buildings with varying height from 3 to $27.3 \mathrm{~m}$. The buildings had a varying arrangement of escape routes and rooms, and obstacles on escape routes, such as doors or local pinch points. They differed in the length and width of escape routes and the number of users. For each building model an evacuation simulation was prepared in three variants, providing a total of 60 computer simulations. In the first variant of the simulation, e.g. simulation No. 1, an assumption was made that in each office room there is 1 persons, in the second
Model stosować można w przypadku występowania zagęszczenia ludzi na drogach ewakuacyjnych od 0,3 do 3,2 osoby $/ \mathrm{m}^{2}$. Wartość ta wynika z danych literaturowych [7] oraz własnych danych doświadczalnych. Zakres taki obejmuje zdecydowaną większość rzeczywistych ewakuacji ludzi z budynków. Po uwzględnieniu w zaproponowanym modelu (8) wymienionych wyżej wartości współczynnika korekcyjnego A, w tabeli 3 przedstawiono porównanie czasów eksperymentalnych oraz tych obliczonych ze zmodyfikowanego modelu.

Analiza wyników zawartych $w$ tabeli 3 pozwala stwierdzić, że obliczone czasy ewakuacji z zaproponowanego zmodyfikowanego modelu (8) obarczone są błędem wynoszącym od $-12,3 \%$ do $+13,8 \%$ w stosunku do czasów eksperymentalnych. Można na tej postawie stwierdzić, że zaproponowane równanie (8) do obliczania czasu ewakuacji ludzi z budynków daje wyniki bardzo zbliżone do tych uzyskanych w drodze eksperymentów w ramach niniejszej pracy. Porównania potwierdziły, że wzór (8) pozwala na obliczanie czasów ewakuacji dla budynków o bardzo różnej geometrii oraz liczbie użytkowników. Co ważniejsze, także w stosunku do niezależnego badania przeprowadzonego przez badaczy w jednym z wysokościowych budynków o funkcji użyteczności publicznej i mieszkalnej (ewakuacja 286 osób z kondygnacji +49 $i+50$ ), odchylenie obliczonego z modelu czasu ewakuacji obarczone było błędem $-11,5 \%$. W większości przypadków otrzymane czasy ewakuacji są nieznacznie przeszacowane, co z punktu widzenia ochrony przeciwpożarowej jest zjawiskiem korzystnym.

Równanie (8) daje również dobry opis danych doświadczalnych nawet $w$ bardzo rzadko występującym w praktyce przypadku, gdy gęstość ewakuujących się ludzi jest bardzo mała, poniżej 0,3 osoby $/ \mathrm{m}^{2}$ na poziomych drogach ewakuacyjnych oraz 0,2 osoby $/ \mathrm{m}^{2}$ dla drogach pionowych. W takim przypadku wartość współczynnika korekcyjnego $A$ wynosi $A=5$. Natomiast $w$ bardzo rzadkich przypadkach bardzo dużego zagęszczenia ewakuujących się ludzi - przekraczającego 3 osoby $/ \mathrm{m}^{2}$ na poziomej drodze ewakuacyjnej - współczynnik korekcyjny wynosi $A=0,3$, a dla pionowej drogi ewakuacyjnego przy gęstości ludzi powyżej 3,2 osoby $/ \mathrm{m}^{2}$ równa się 0,1. Zostało to jednak potwierdzone dla nielicznych danych doświadczalnych. W związku z czym zaproponowany w pracy model został potwierdzony dla bardzo wielu przypadków ewakuacji w zakresie gęstości ewakuujących się ludzi od 0,3 do 3,2 osoby/m².

W związku z powyższym można przyjąć, że równanie (8) jest narzędziem uniwersalnym i możliwym do stosowania do wyznaczania czasów ewakuacji ludzi z różnych budynków użyteczności publicznej ZL III z zadawalającą dokładnością.

W celu dodatkowej weryfikacji zaproponowanego równania modelowego (8) do wyznaczania czasu ewakuacji ludzi przeprowadzono szereg symulacji komputerowych ewakuacji za pomocą programu Pathfinder wykorzystującego model zmienno-sterujący. Symulacje komputerowe wykonano dla 20 różnych geometrii budynków użyteczności publicznej, o różnej wysokości od 3 do 27,3 m. Budynki posiadały różny układ dróg ewakuacyjnych, rozkład pomieszczeń, zakłóceń występujących na drogach ewakuacyjnych w postaci drzwi lub lokalnych przewężeń. Różniły się między sobą długością i szerokością dróg ewakuacyjnych oraz liczbą użytkowników. Dla każdego zbudowanego modelu budynku wykonano symulację ewakuacji w trzech wariantach, co w sumie daje 60 symulacji 
variant there were 3 people, and in the third -6 people. The described arrangement of building users made it possible to achieve various densities of people on horizontal and vertical escape routes. Figure 4 presents an example of a model made with the Pathfinder software for the simulation identified in table 4 (number 38).

Table 4 contains a list of evacuation times obtained with the Pathfinder software and with the proposed model equation for estimating evacuation times (8) arrived at by modifying Greenberg's model and determining deviations of the results from the ones from computer simulations. komputerowych. W pierwszym wariancie symulacji np. symulacji nr 1 założono, że w każdym pomieszczeniu biurowym znajduje się po 1 osobie, w drugim wariancie symulacji po 3 osoby, a w trzecim po 6 osób. Taki rozkład użytkowników budynku pozwolił na otrzymanie różnej gęstości ludzi na poziomych i pionowych drogach ewakuacyjnych. Na rycinie 4 przedstawiono przykładowy model wykonany za pomocą programu Pathfinder dla symulacji wskazanej w tabeli 4 odpowiadającej numerowi 38.

W tabeli 4 przedstawiono zestawienie czasów ewakuacji otrzymanych za pomocą programu Pathfinder oraz czasów ewakuacji otrzymanych za pomocą zaproponowanego w pracy równania modelowego szacowania czasu ewakaucji (8), uzyskanego przy zastosowaniu modyfikacji modelu Greenberga wraz z określeniem wielkości odchyleń wyników w stosunku do czasu uzyskanego z przeprowadzonych symulacji komputerowych.

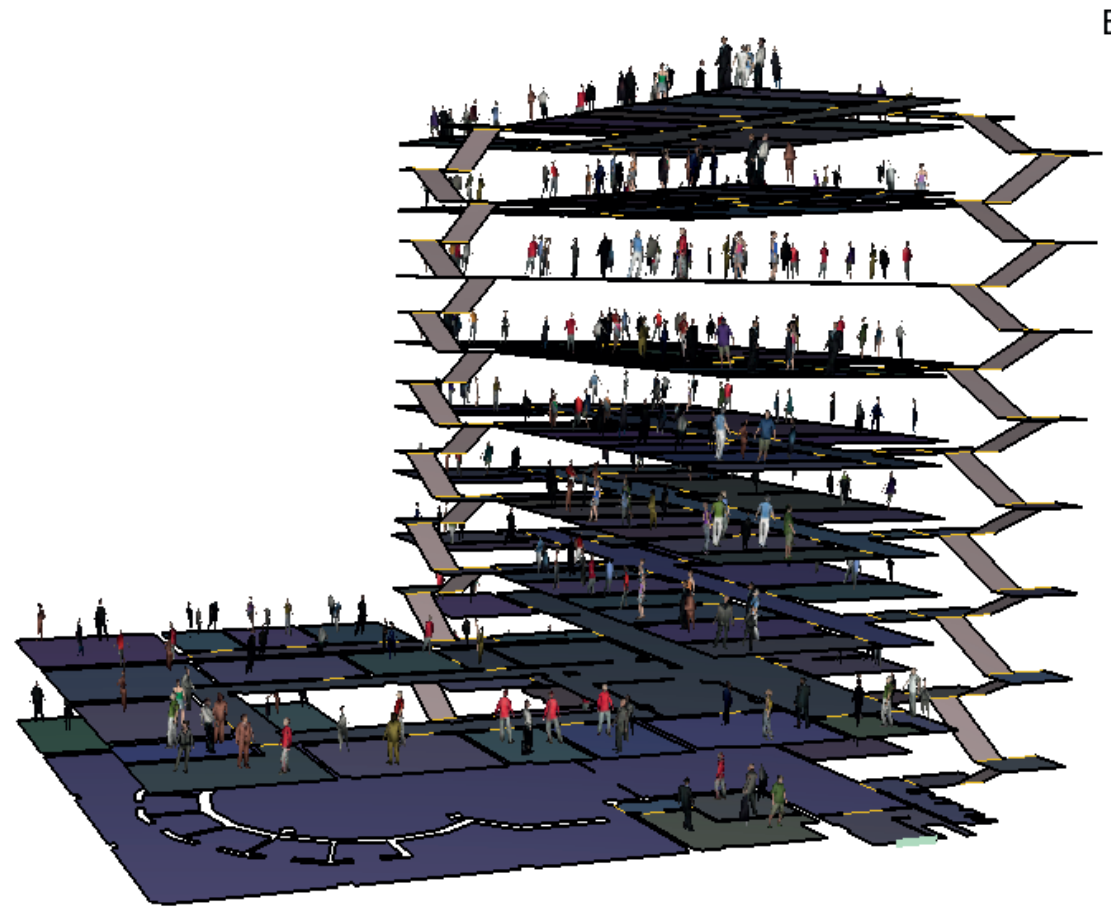

Ewakuowani : $\quad 0 / 381$

Figure 3. The commencement of the No. 38 computer simulation, in which it was assumed that there were 3 people occupying each office room Rycina 3. Rozpoczęcie symulacji komputerowej nr 38, założono występowanie 3 osób w każdym pomieszczeniu biurowym

Source: Own elaboration.

Źródło: Opracowanie własne.

\section{Summary}

The experimental part included the analysis of the performed tests consisting in practice evacuations of people from buildings. The tests participants were users of public utility buildings assigned to human hazard category ZL III, their employees and customers. These were people aged $20-65$, of both genders, which makes the obtained results reliable and accurately reflecting actual evacuation conditions [8]

\section{Podsumowanie}

W części doświadczalnej poddano analizie przeprowadzone badania polegające na obserwacji próbnych ewakuacji ludzi z budynków. W badaniach brały udział osoby będące użytkownikami obiektów użyteczności publicznej, kwalifikowanych do kategorii zagrożenia ludzi ZL III, ich pracownicy i petenci. Były to osoby w wieku od 20 do 65 lat, różnej płci, co czyni uzyskane wyniki wiarygodnymi, dobrze reprezentującymi rzeczywiste warunki ewakuacji [8]. 
Table 4. The juxtaposition of time values obtained from computer simulations and the estimates of evacuees' movement time established with the proposed model equation (8)

Tabela 4. Zestawienie czasów uzyskanych podczas symulacji komputerowych z czasami przemieszczania się ewakuujących się osób obliczonymi za pomocą zaproponowanego modelowego równania (8)

\begin{tabular}{|c|c|c|c|c|}
\hline & \multirow{2}{*}{$\begin{array}{c}\text { Simulation } \\
\text { number } \\
\text { Numer } \\
\text { symulacji }\end{array}$} & \multirow{2}{*}{$\begin{array}{l}\text { Simulation time [s] } \\
\text { Czas symulacji [s] }\end{array}$} & \multicolumn{2}{|c|}{$\begin{array}{l}\text { Equation use estimate of evacuation time (8) } \\
\text { Czas ewakuacji obliczony z zaproponowanego równania (8) }\end{array}$} \\
\hline & & & Evacuation time [s] / Czas ewakuacji [s] & Deviation [\%] / Odchylenie wyniku [\%] \\
\hline 1 & & 30.1 & 27.3 & -9.2 \\
\hline 2 & & 31.1 & 33.0 & +9.5 \\
\hline 3 & & 38.5 & 38.4 & -0.1 \\
\hline 4 & & 26.2 & 25.6 & -2.3 \\
\hline 5 & & 38.9 & 40.9 & +5.0 \\
\hline 6 & & 44.5 & 53.6 & +20.5 \\
\hline 7 & & 73.4 & 72 & -1.9 \\
\hline 8 & & 94.3 & 100.8 & +6.9 \\
\hline 9 & & 137.7 & 141.8 & +3.0 \\
\hline 10 & & 78.0 & 85.9 & +10.2 \\
\hline 11 & & 154.3 & 158.2 & +2.5 \\
\hline 12 & & 315.3 & 349.7 & +10.9 \\
\hline 13 & & 33.5 & 30.4 & -9.3 \\
\hline 14 & & 40.5 & 45.8 & +13.1 \\
\hline 15 & & 49.3 & 57.3 & +16.3 \\
\hline 16 & & 55.4 & 65.9 & +18.9 \\
\hline 17 & & 95.7 & 118.6 & +12.2 \\
\hline 18 & & 123.4 & 137.1 & +11.1 \\
\hline 19 & & 65.5 & 67.5 & +3.1 \\
\hline 20 & & 126.9 & 119.9 & -5.5 \\
\hline 21 & & 176.9 & 201.1 & $+13,7$ \\
\hline 22 & & 77.0 & 79.0 & +2.6 \\
\hline 23 & & 154.0 & 137.1 & -11.0 \\
\hline 24 & & 233.0 & 286.6 & +23.1 \\
\hline 25 & & 88.3 & 91.4 & $+3,5$ \\
\hline 26 & & 193.5 & 175.0 & -9.6 \\
\hline 27 & & 294.3 & 342.1 & +16.2 \\
\hline 28 & & 95.3 & 109.5 & +14.9 \\
\hline 29 & & 223.2 & 195.5 & -12.4 \\
\hline 30 & & 341.6 & 403.4 & +18.1 \\
\hline 31 & & 105.9 & 121.7 & +15.0 \\
\hline 32 & & 253.0 & 216.0 & -14.6 \\
\hline 33 & & 408.1 & 430.0 & +5.4 \\
\hline 34 & & 118.9 & 134.0 & +12.7 \\
\hline
\end{tabular}




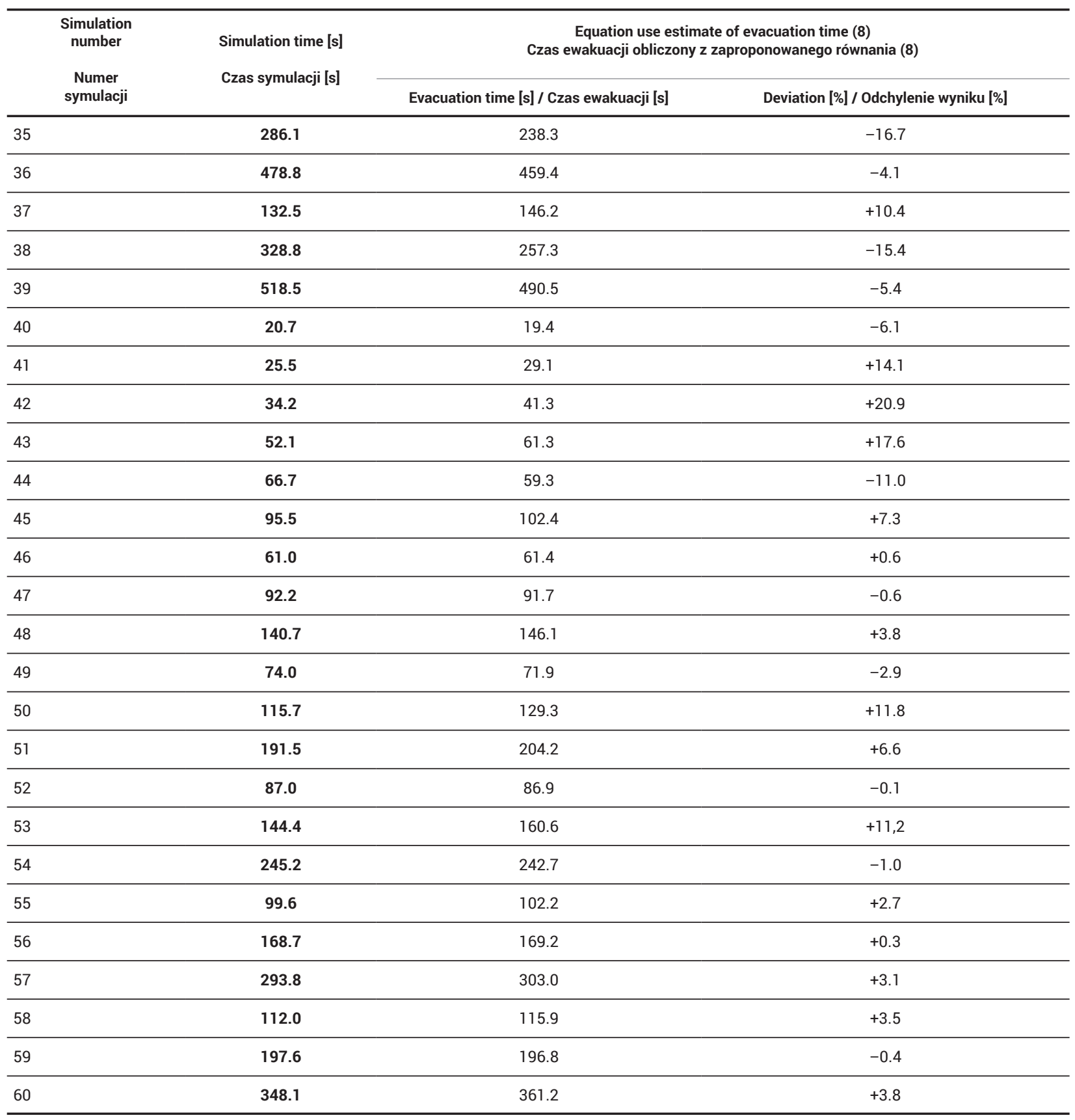

Source: Own elaboration.

Źródło: Opracowanie własne.

Based on the analogy between road traffic and people moving during the evacuation process, the use of a modified Greenberg's model was suggested [equation (8)], as a simple tool for estimating people's evacuation times in public utility buildings of category ZL III. It takes into account varying velocities of people moving along vertical and horizontal escape routes, a tendency to slow down when the direction of movement changes, and the impact of obstacles found on escape routes on evacuation time.

The evacuation times calculated with the proposed equation (8) were in line with experimental results with a bias from
Wykorzystując analogię pomiędzy teorią ruchu drogowego pojazdów a przemieszczającymi się ludźmi w trakcie ewakuacji, zaproponowano zastosowanie modyfikacji modelu Greenberga - równania (8) jako prostego narzędzia do szacowania czasu ewakuacji ludzi w budynkach użyteczności publicznej ZL III. Uwzględnia ono zróżnicowanie prędkości przemieszczających się ludzi po pionowych i poziomych drogach ewakuacyjnych, tendencję do zwalniania przy zmianie kierunku ruchu, a także wpływ utrudnień występujących na drogach ewakuacyjnych na czas ewakuacji.

Obliczone czasy ewakuacji za pomocą zaproponowanego równania (8) zgadzały się z wynikami eksperymentalnymi 
$-12.3 \%$ to $+13.8 \%$ (see table 2 ). However, in comparison with times obtained in additional computer simulations representing evacuation from buildings with varying geometries and number of evacuees (see table 3 ), deviation of the evacuation time calculated from the proposed model was from $-16.7 \%$ to $+23.1 \%$. In a considerable majority of cases the result's deviation was around $\pm 15 \%$ for a broad range of building geometries and various numbers of evacuees.

The authors' experiments on the basis of which the suitability of the proposed model for estimating people's evacuation time from public utility buildings was verified confirm its universality. It can be applied to determine the duration of single-stage evacuation of the whole building as well as multistage evacuation (of the respective storeys) in buildings in which the density of people on the evacuation path is lower than 3.2 persons per sq. $\mathrm{m}$.

Taking into consideration the diversity of selected research objects and the stochastic nature of evacuation, it is possible to state that the evacuation times determined with the proposed model equation (8) which contains a number of simplifications reflect in a satisfactory manner actual evacuation times specified for buildings with varying geometries, and numbers of users varying in terms of age, gender and physical abilities.

\section{Literature / Literatura}

[1] Cłapa I., Porowski R., Dziubiński M., Wybrane modele obliczeniowe czasów ewakuacji, BiTP Vol. Issue 4, 2011, pp. 71-79.

[2] Orłowska I., Dziubiński M., Porównanie modelowych czasów ewakuacji z przeprowadzonymi eksperymentami, BiTP Vol. 50, Issue 2, 2018, pp. 108-119, https://doi.org.10.12845/bitp.50.2.2018.8.

[3] Datka S., Suchorzewski W.,Tracz M., Inżynieria ruchu, WKit, Warszawa 1989.

[4] Rozporządzenie Ministra Infrastruktury z dnia 12 kwietnia 2002 r. w sprawie warunków technicznych jakim powinny odpowiadać budynki i ich usytuowanie (Dz. U. z 2015 r. poz. 1422 ze zm.).

[5] Procedury organizacyjno-techniczne $w$ sprawie spełnienia wymagań w zakresie bezpieczeństwa pożarowego w inny sposób niż to określono w przepisach techniczno-budowlanych, w przypadkach wskazanych w tych przepisach, oraz stosowania rozwiązań zamiennych, Komenda Główna PSP, Warszawa 2008. z błędem od $-12,3 \%$ do $+13,8 \%$ (patrz tabela 2 ). Natomiast w porównaniu z czasami uzyskanymi z dodatkowych symulacji komputerowych, reprezentujących opis ewakuacji z budynków o bardzo różnej geometrii i różnej liczbie ewakuujących się ludzi (patrz tabela 3), odchylenie wyniku obliczanego czasu ewakuacji z zaproponowanego modelu wyniosło od $-16,7 \%$ do $+23,1 \%$. W zdecydowanej większości przypadków odchylenie wyniku oscylowało w granicach około $\pm 15 \%$ dla szerokiej gamy geometrii budynków oraz różnej liczby ewakuujących się osób.

Przeprowadzone własne eksperymenty, w oparciu o które zweryfikowano przydatność zaproponowanego modelu do szacowania czasu ewakuacji ludzi z budynków użyteczności publicznej, potwierdzają jego uniwersalność. Można go zastosować do wyznaczania czasu ewakuacji jednoetapowej - całego budynku, jak również w przypadku ewakuacji etapowej (poszczególnych kondygnacji) w obiektach, w których zagęszczenie ludzi na drodze ewakuacyjnej jest mniejsze od 3,2 osoby $/ \mathrm{m}^{2}$.

Mając na uwadze różnorodność wybranych obiektów badawczych oraz stochastyczny charakter ewakuacji, można uznać, że otrzymane czasy ewakuacji wyznaczone za pomocą zaproponowanego modelowego równania (8) zawierającego wiele uproszczeń - w zadowalający sposób odzwierciedlają rzeczywiste czasy ewakuacji określone dla budynków o zróżnicowanej geometrii, liczbie i różnorodności co do wieku, płci, sprawności fizycznej użytkowników.

[6] Małolepszy R., Wymagany idostępny czas bezpiecznej ewakuacji - metodyka obliczania, Materiały konferencyjne: Ochrona przeciwpożarowa, Zakopane 2010.

[7] BS 7974:2001 - załącznik PD 7974-6:2004, The application of fire safety engineering principles to fire safety design of buildings. Part 6 . Human factors: Life safety strategies - Occupant evacuation, behaviour and condition (Sub-system 6).

[8] Gwynne S.M.V., Purser D., Boswell D.L., Pre-warning staff delay: A forgotten Component in ASET/RSET calculations, in: Pedestrian and Evacuation Dynamics, Springer, London 2010, 243-253.

[9] Cote A.E., Fire Protection Handbook, National Fire Protection Association, 2003.

[10] Paliszek-Saładyga J., Smardz P., Weryfikacja koncepcji bezpieczeństwa pożarowego budynku wysokościowego - połączona próba dymowa i ewakuacyjna, Materiały konferencyjne: Ochrona przeciwpożarowa, Zakopane 2016 .
IWONA ORŁOWSKA, PH.D. ENG. - she graduated from the Faculty of Fire Safety Engineering at the Main School of Fire Service in Warsaw. She is an officer of the State Fire Service. Currently a Ph.D. student at the Faculty of Process and Environmental Engineering of the Lodz University of Technology. Her principal research interests involve the numerical modelling of evacuation processes and fire safety engineering.
DR INŻ. IWONA ORŁOWSKA - funkcjonariusz PSP, absolwentka Wydziału Inżynierii Bezpieczeństwa Pożarowego Szkoły Głównej Służby Pożarniczej w Warszawie. Obecnie doktorantka na Wydziale Inżynierii Procesowej i Ochrony Środowiska. Obszar zainteresowań naukowych to modelowanie numeryczne procesów ewakuacji oraz inżynieria bezpieczeństwa pożarowego. 
PROF. MAREK DZIUBIŃSKI, D.SC. ENG. - a research fellow at the Lodz University of Technology, currently serves as the Head of the Department of Chemical Engineering at the Faculty of Process Engineering and Environmental Protection. His scientific interests revolve around multiphase flows, with particular emphasis on Newtonian and non-Newtonian liquid-gas liquid flows, rheology and technical rheometry, risk and process safety elements (single- and twophase outflows from pipelines and reservoirs), and the maintenance of emulsions and their properties.
PROF. DR HAB. INŻ. MAREK DZIUBIŃSKI - pracownik naukowy Politechniki Łódzkiej. Na tej uczelni obecnie pełni funkcję kierownika Katedry Inżynierii Chemicznej na Wydziale Inżynierii Procesowej i Ochrony Środowiska. Naukowo interesuje się: przepływami wielofazowymi ze szczególnym uwzględnieniem przepływów dwufazowych ciecz - gaz cieczy newtonowskich i nienewtonowskich, reologią i reometrią techniczną, elementami ryzyka i bezpieczeństwa procesowego (wypływy jedno- i dwufazowe z rurociągów i zbiorników) oraz utrzymywaniem emulsji i ich właściwościami. 